\title{
Allele Frequencies of MYCL and MYB Protooncogenes in Unrelated Healthy Japanese
}

To the Editor:

Polymorphic DNA segments detected by restriction fragment length polymorphisms (RFLPs) are used as markers for inherited human diseases, and also for studying malignancies, the objective being to search for possible associations with tumor predisposition and/or progression. We studied the allele frequencies of MYCL and MYB in unrelated healthy Japanese. In the two loci, EcoRI RFLPs which were explained by a diallelic system have been reported (Table 1).

The RFLPs of MYCL and MYB were studied using Southern blot analyses in the EcoRI-digested placental DNAs (27 males and 24 females) obtained from 51 healthy Japanese obstetrical patients. The Mendelian inheritance was confirmed in peripheral blood samples obtained from 6 members of a single family. Probes were prepared from the following plasmids: Vector/probe size/cloning site is pJB327/1.8 kb/SmaI-EcoRI for MYCL (Nau et al., 1985) and pBR322/2.6 kb/ EcoRI for MYB (Franchini et al., 1983), kindly provided by Dr. J. D. Minna and Dr. S. R. Tronick through the Japanese gene bank of JCRB, respectively.

The allele frequencies obtained are presented in Table 1. Data on European Caucasians are listed for comparison. Differences between Japanese and Caucasians were not statistically significant in both loci by chi-square test and between Japanese males and females (MYCL: $\mathrm{p}>0.5$, MYB: $\mathrm{p}>0.1$, data not shown). The frequency of MYCL alleles was also obtained in a larger number of Japanese, A1: 0.46 and A2: 0.54, by Dr. M. Yamada (Natl. Children's Med. Res. Ctr., personal communication), which was consistent with our result. Our data confirmed the reports on European Caucasians in Table 1, suggesting the RFLPs of these genes occurred before differentiation of human races.

Table 1. Allele frequencies of two protooncogenes, MYCL and MYB, in unrelated Japanese and in Caucasians.

\begin{tabular}{llccccc}
\hline Symbol & Allele size $(\mathrm{kb})$ & $\mathrm{N}^{\circ} \mathrm{CHR}$ & $\begin{array}{c}\text { Japanese } \\
\text { freq }\end{array}$ & $\mathrm{N}^{\circ} \mathrm{CHR}$ & $\begin{array}{c}\text { Caucasian } \\
\text { freq }\end{array}$ & $\chi^{2}(\mathrm{p})$ \\
\hline $\mathrm{MYCL}$ & A1 10 & 102 & 0.41 & $90^{\mathrm{a}}$ & 0.43 & 0.079 \\
& A2 6.6 & & 0.59 & & 0.57 & $(>0.7)$ \\
$\mathrm{MYB}$ & A1 2.6 & 102 & 0.44 & $98 \mathrm{~b}$ & 0.48 & 0.322 \\
& A2 $1.55,1.05$ & & 0.56 & & 0.52 & $(>0.5)$ \\
\hline
\end{tabular}

a Farndon and Simmons (1987), b Dozier et al. (1986).

Received July 17, 1989; revised version received August 10, 1989; Accepted August 17, 1989. 
We thank M. Ohara of Kyushu University for comments on the manuscript.

\title{
REFERENCES
}

Dozier, C., Walbaum, S., Leprince, D. and Stehelin, D. 1986. EcoRI RFLP linked to the human myb gene. Nucleic Acids Res. 14: 1928.

Farndon, P.A. and Simmons, J. 1987. LOD scores for markers on chromosome 1. Cytogenet. Cell Genet. (HGM 9) 46: 612.

Franchini, G., Wong-Staal, F., Baluda, M.A., Lengel, C. and Tronick, S.R. 1983. Structural organization and expression of human DNA sequences related to the transforming gene of avian myeloblastosis virus. Proc. Natl. Acad. Sci. U.S.A. 80: 7385-7389.

Nau, M.M., Brooks, B.J., Battey, J., Sausville, E., Gazdar, A.F., Kirsch, I.R., McBride, O.W., Bertness, V., Hollis, G.F. and Minna, J.D. 1985. L-myc, a new myc-related gene amplified and expressed in human small cell lung cancer. Nature 318: 69-73.

\author{
Masako TADA, ${ }^{1}$ Michiko OKadA ${ }^{1, *}$ Naotoshi Kanda, ${ }^{3}$ \\ Sayuri Aiba, ${ }^{2}$ Yoshiko Sasamoto, ${ }^{2}$ Chizu Ishikawa, ${ }^{2}$ \\ Kura Kubota, ${ }^{1}$ and Yoshiko Nomura ${ }^{1}$ \\ ${ }^{1}$ Chromosome Laboratory and ${ }^{2}$ Division of Obstetrics and Gynecology, \\ Shiseikai Dai-Ni Hospital, \\ 5-19-1 Kamisoshigaya, Setagaya-ku, Tokyo 157, Japan \\ 'Department of Anatomy, Tokyo Women's Medical College, \\ 8-1 Kawada-cho, Shinjuku-ku, Tokyo 162, Japan
}

\footnotetext{
* To whom correspondence should be addressed.
} 